\title{
Historic Maps and Archaeology as a Means of Understanding Late Precolonial Settlement in the Banda Islands, Indonesia
}

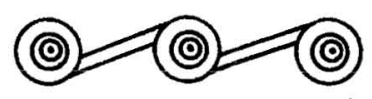

PETER V. LAPE

ARCHAEOLOGICAL STUDIES OF SETTLEMENT PATTERNING have provided useful data for understanding the process of cross-cultural interaction in many parts of the world. These studies have highlighted how shifts in settlement locations, regional organization of settlements, and spatial relationships between settlements and resources can be linked to evidence for cross-cultural contact and interaction. Contextualizing other evidence about the process and effects of cross-cultural interaction with settlement pattern shifts often evokes more powerful explanations about how people accommodate foreigners in their lives (Cusick 1998; Insoll 1999; Kirch and Sahlins 1992; Ucko and Layton 1999).

In some cases of cross-cultural interaction, such as at the sites of European colonial projects in Africa, Asia, and the New World, historic maps can provide a valuable data set relating to settlement pattern changes. While maps are recognized as being particularly prone to biases of their makers and publishers, a comparison with archaeological settlement data can provide useful interpretive insights into both data sets. Below I provide a case study of the use of historic maps and archaeological data for understanding the relationship between changing settlement patterns and the arrival of foreign traders, including Asians and Europeans, to the Banda Islands of Eastern Indonesia in the fifteenth to seventeenth centuries (Fig. 1). These 11 islands were once the world's sole source of nutmeg and mace, and became the site of some of the fiercest struggles for trade and colonial dominance in the early modern era. The Banda islanders first encountered Europeans in A.D. 1512, with the arrival of the first Portuguese trading ships. Just over a century later in 1621, the Bandas were irrevocably changed when Dutch East India Company (VOC) forces, aided by Japanese mercenaries, massacred, enslaved, or banished some 90 percent of Banda's population. Dutch farmers and their Asian slaves subsequently repopulated the islands, the first footholds in what became the Dutch colonial empire in the East Indies (Hanna 1978; Loth 1995a, 1995b, 1998; Masselman 1963; van der Chijs 1886).

Peter Lape is an assistant professor in the Department of Anthropology, University of Washington, Seattle.

Asian Perspectives, Vol. 41, No. 1 (C) 2002 by University of Hawai'i Press. 

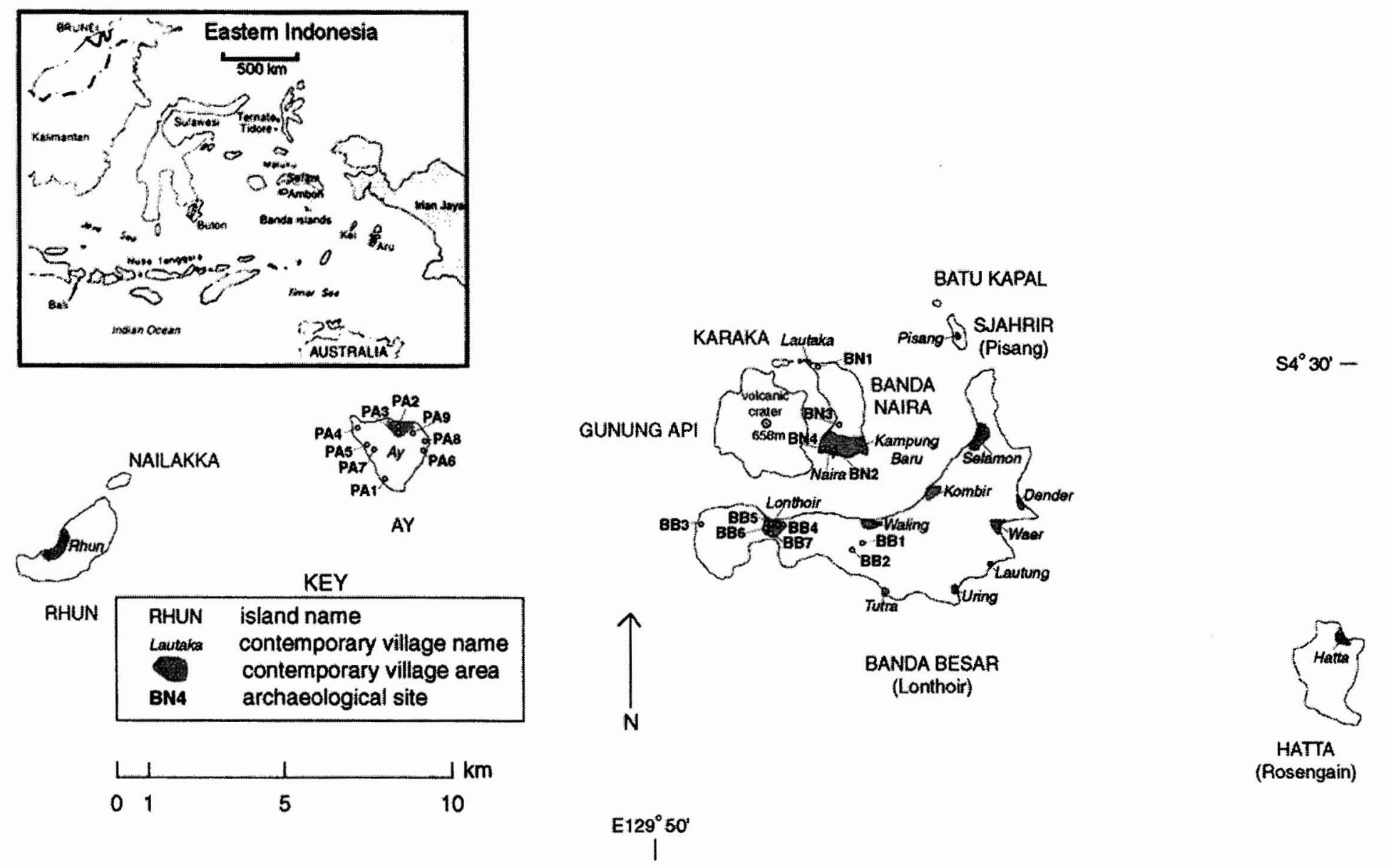

Fig. 1. Archaeological sites in the Banda Islands. 
The data gathered from historic maps and other documents combined with archaeological data provided the basis for my interpretation of the late precolonial history of the islands (tenth to seventeenth centuries). A more detailed analysis is available in other publications (Lape 2000b, 2000c). This article will focus on the use of historic maps in hopes that both their utility and their limitations for archaeologists can be more widely understood.

\section{DATA CATEGORIES AND BIASES}

While historic maps are the primary documentary data considered here, I have attempted to view and contextualize them within a larger corpus of written documents, including reports, ships logs, letters, diaries, treaties and agreements, and pictorial representations, including engravings, paintings, plans, and views. Secondary literature also provided colonial and postcolonial perspectives (e.g., Abdurachman 1978; Andaya 1991, 1993; "Answer" 1971; Argensola 1708; Arthus 1628; Barbosa 1921; Blussé 1986; Bohigian 1994; Chaudhuri 1990; Goodman 1998; Leirissa 1978, 1994; Marr and Milner 1988; Meilink-Roelofsz 1962; Ptak 1998, 1999; Purchas and Hakluyt 1625; Reid 1988, 1993b; Ricklefs 1993; Rumpf and Beekman 1981, 1999; Schrieke 1960; Schurhammer 1962; Stoler 1985; Swadling 1996; Taylor 1983; Tibbetts 1979). Oral histories were also considered in this research, but will only be touched on briefly here (see Lape $2000 \mathrm{~b}$ for additional analyses of other categories of documentary and oral traditions data). I found it most useful to begin interpretations of historic maps from the basis of these other documentary sources before casting these data against the archaeological record. However, the archaeological data also served to generate questions back against the documentary data during the research process.

In this study, maps were used to provide insights about the names, locations, and in some cases the relative sizes of settlements in Banda. Maps also provided a glimpse into how the mapmaker saw his world (and all the maps considered here appear to have been authored by men). Maps depict selected abstractions of real geographic space, reflecting conscious or subconscious selections made by the mapmaker (Harvey and Holly 1981). These choices can be analyzed to understand general attitudes held by the mapmaker about that geographic space and about the people who lived in it.

The archaeological data were also subject to constraints and resulting biases. The Maluku region of Eastern Indonesia is relatively unexplored archaeologically, with most previous work oriented towards periods predating the tenth to seventeenth centuries (Ballard 1987; Bellwood 1998; Ellen and Glover 1974; Spriggs 1990, 1998; Spriggs and Miller 1979, 1988; Spriggs et al. 1998; Stark and Latinis 1992, 1996; Veth et al. 1996). In Banda, my research includes the first archaeological excavations carried out on the islands. This lack of previous research in Banda and limited regional studies undoubtedly contributes to a skewed view of Banda's past, which will hopefully be corrected as additional research is carried out.

One example of bias particularly relevant to this paper is the current picture of settlement patterning obtained from the limited number of excavated and dated sites in Banda. Archaeological sites on the islands are often invisible from the sur- 
face due to rapid deposition of volcanic tephra from the active Gunung Api volcano, dense vegetation, or recent construction and development. Volcanic tephra deposition varied depending on location. The outer uplifted limestone island of Pulau Ay, for example, showed much lower rates of tephra deposition, and artifacts dating to 2000-3000 B.P. were visible on the ground surface in areas disturbed by agricultural activities. For the inner volcanic islands of Banda Naira and Banda Besar, sites were discovered through test excavation in areas that met certain geographic parameters assumed to be desirable for settlement in the late precolonial period, such as proximity to protected beaches and harbors where boats could land. Survey and test excavations were carried out only on portions of the three islands of Pulau Ay, Banda Besar, and Banda Naira. Settlement sites identified archaeologically to date are shown in Figure 1, although it is clear that they represent a partial window into past land use (see Lape $2000 \mathrm{~b}$ for a detailed discussion of survey and excavation strategies). However, I will argue here that even these very incomplete and biased data can help us to interpret historic map data, and likewise, historic map data can help to extend the usefulness of incomplete archaeological settlement data.

\section{SIXTEENTH- AND SEVENTEENTH-CENTURY MAPS IN CONTEXT}

The motivations behind the making of maps were (and still are) multiple and sometimes conflicting. In many cases, maps were made to help future travelers find their way. For traders, the names and locations of principal market or trading towns were crucial. However, maps also served political purposes, and for these reasons the information on maps may have been deliberately misleading. For example, trading companies may have hidden the location of potentially profitable trading locations to gain an advantage over competitors (Harley and Woodward 1987; Suarez 1999; Zandvliet 1998). As these companies were entangled in national interests, they may have altered the geographical location of places to bring them under their political realm to conform to existing treaties. Treaties made with native groups may have also influenced mapmaking. Groups or settlements that refused to sign over monopoly privileges may have been excluded from maps to make it seem as though there was unanimous consent for such treaties (cf. for other colonial situations, Fisher and Johnston 1993; Galloway 1995; Stahl 2001). Areas that resisted foreign control, or allied with an enemy may have been shown as empty, devoid of settlement, in some cases simply because a mapmaker was denied access to them (Suarez 1999:235-236; Trouillot 1995; Winer 1995).

Other unintentional errors creep into the texts written on maps. The transcription of unfamiliar languages into European phonology may have meant that places with unpronounceable names (for Europeans) were altered. Because maps of Banda were often made after rather short visits to the islands, misunderstandings, incomplete knowledge, and confusions may have altered the place names we now see on old maps. Places in Banda probably had multiple names in the past as they do today, including sacred names and names for everyday use. Language change on Banda itself, stimulated by the increasing numbers of foreigners who settled there, may have altered place names over time. The fact that Europeans gained information through nonindigenous intermediaries such as Turks, Malays, or Javanese, all of whom spoke different languages than the native Bandanese, 
probably altered the toponyms that have been recorded on maps ("Description" 1598; "Tweede" 1601; Valentijn 1724; Wall 1928).

There are dozens of potential biases that could have altered maps from a "true" representation of the physical space of Banda. However, these biases do not simply make the maps less accurate. Geographers and historians have successfully deconstructed maps and teased out new insights into the "social world in which [they] were produced" (Harley 1992:232). Historical archaeologists have similarly used maps as one set of documentary data to cast against other kinds of data as a sort of test or comparison (e.g., Hall 2000; Winer 1995). By contextualizing and comparing maps of late precolonial Banda with other maps and the documentary and archaeological record, they can help us understand the mindset of European visitors to Banda, and cultural process at work there. What mapmakers saw and how they conceived of the geographical space of Banda was, in part, determined by and determinant of the cultural encounter between the various European and Asian groups present in Banda. When compared against the archaeological record, many biases can be exposed, and their power as data considerably enhanced.

\section{SETTLEMENT CHANGE AS DEPICTED IN MAPS OF BANDA, A.D. I 599-I623}

In the course of archival research I located 15 different maps depicting the preand early colonial Banda Islands that had settlement-level detail, dating from 1570 to 1680 . These were located in a wide variety of private collections, archives, and published sources, and are discussed in detail in my dissertation (Lape 2000b). Five of those maps are discussed here to illustrate their use in conjunction with archaeological data. The first appearance of Banda on surviving world maps dates to an anonymous mappamundi of 1457 , which was probably informed by the account of Nicoló de'Conti, who claimed to have visited the islands (Suarez 1999:79). Another early map showing Banda is the Rodrigues Map, which was probably copied from an Asian-drawn map used by the first Portuguese expedition to the islands in 1512 (Cortesão and Mota 1987: pl. 22; Lape 2000b:84-85; Nakamura 1963:28-32; Sollewijn Gelpke 1995); however, neither of these maps show individual settlements. The earliest map to do that in detail is the van Neck Map, ${ }^{1}$ which was first published in 1601, immediately after the Dutch expedition commanded by Cornelius van Neck returned to Holland from Banda and the East Indies (Fig. 2; see also Fig. 7 for a summary view of the historic map data). This particular map was probably the first detailed map of the Banda Islands published in Europe, and it became extremely influential on subsequent mapmaking and European ideas about the configuration of the islands. It was copied and republished in various atlases and other accounts of the East Indies in Holland, England, and France well into the mid-eighteenth century, despite the fact that much more detailed and accurate maps were available by the 1620 s. Later versions include the Schley Map of post 1621, the Vicenzo Mario Cornelli Map of 1706, and the Prevost Map of 1746.

The van Neck Map is useful for several reasons, most importantly because it illustrates the locations of various places discussed in the published account of the van Neck expedition, which visited Banda in 1599 ("Tweede" 1601). This is the most detailed pre-seventeenth-century account of the people of the Banda Islands and it provides a glimpse into a European conception of the society of the islands. 


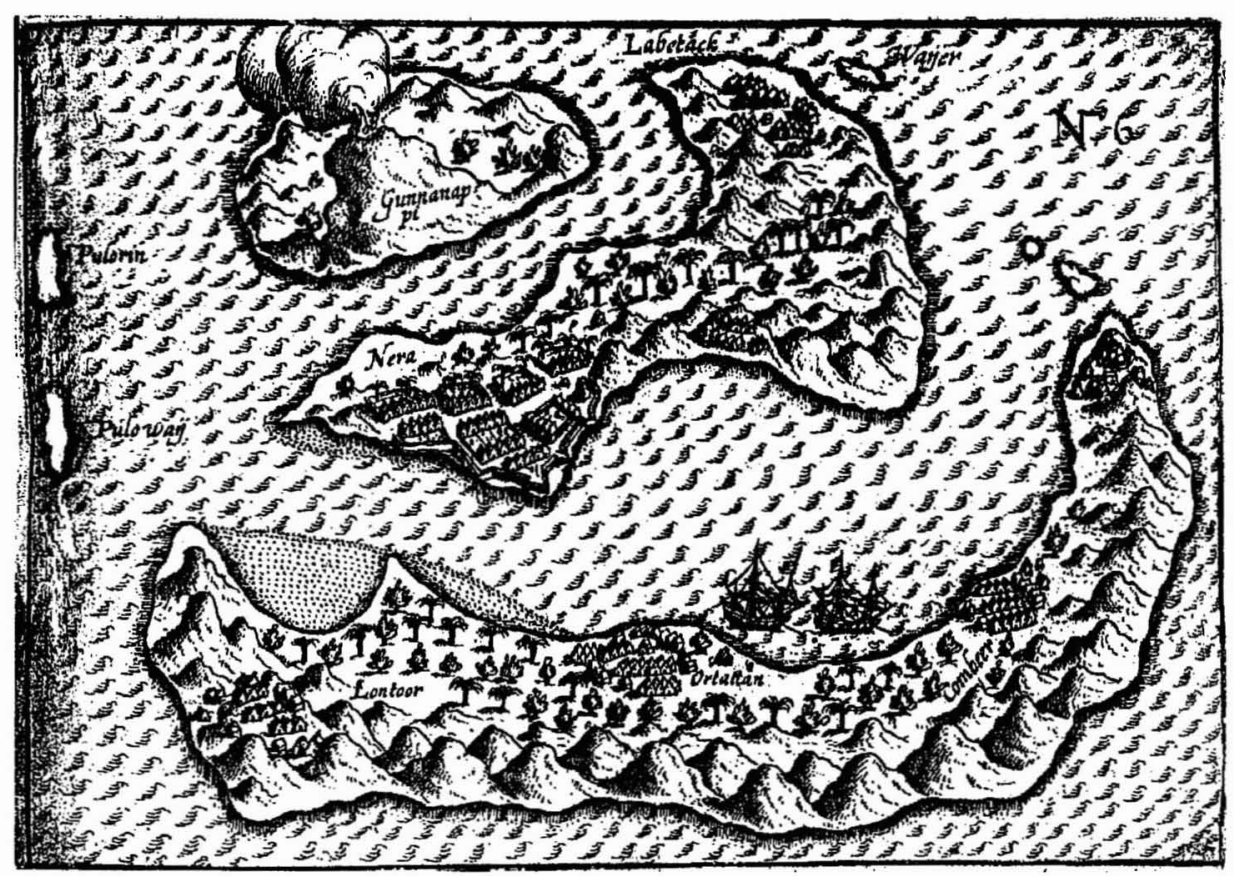

Fig. 2. van Neck map (1599).

The map shows the islands of Gunung Api, Banda Naira, and Banda Besar in the greatest detail, while Rhun, Ay, Pisang, and Batu Kapal are shown in less detail, with no settlements depicted. Hatta Island is not depicted at all. Several settlements are shown as groups of houses, including Lonthor, Ortattan, Combeer, and the vicinity of Selamon (unlabeled) on Banda Besar, while on Banda Naira, settlements called Nera and Labetack are depicted. A group of houses near presentday Tanah Rata is unlabeled. Gunung Api shows no settlements. Ships are shown anchored on the Banda Besar coast between Ortattan and Combeer. A puzzling feature of this map is the small island shown just to the northeast of Banda Naira Island, labeled Wayer. This does not correspond to any contemporary island in place or name. There is a contemporary village called Waer located on the southeast coast of Banda Besar Island. The island on this map may be a misplaced version of the island now named Karaka, located at the entrance to the Naira harbor.

This map seems to be drawn from the perspective of someone on one of the ships shown lying at anchor. From this perspective, the islands of Ay and Rhun look much as they do in this map, small and sitting on the horizon. The island of Hatta is invisible from this perspective, as it is hidden from view by the high ridge of Banda Besar Island, as is the island of Karaka (hidden behind the hills of Banda Naira and Gunung Api). It is possible that the mapmaker rarely or never left the ship, as was recommended in Linschoten's account (1885), which this voyage almost certainly used as a guide. According to the van Neck chronicle, the expedition only visited inner harbor towns. This would suggest that these inner settlements were the primary places of contact and trade with the world to the west. 


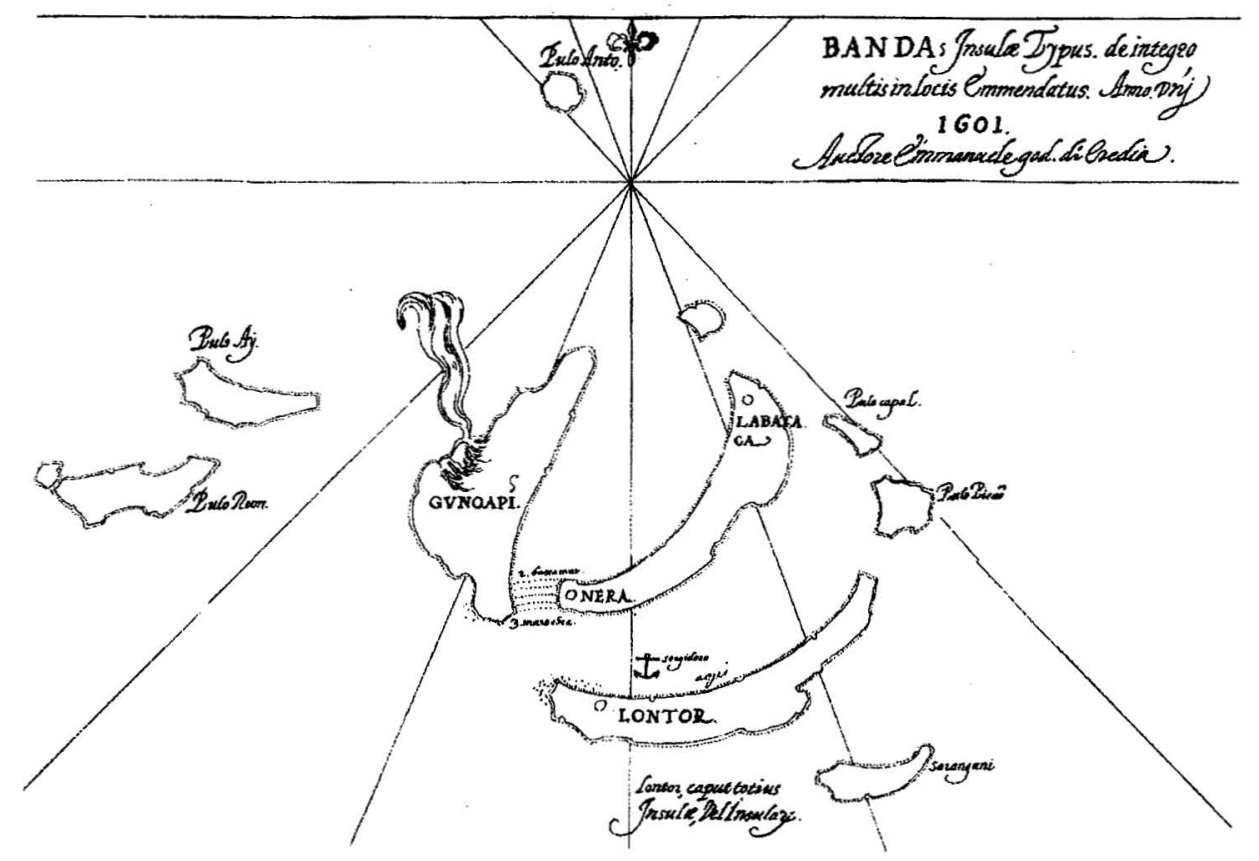

Fig. 3. Eridia map (1602).

Inscribed on this map is a tantalizing clue about the defensive posture of the settlement of Nera; the map shows a wall running along the seaward boundary of the settlement. While walled cities were uncommon in island Southeast Asia before the sixteenth century, by the early seventeenth century walls were built on the seaward sides of most of the trading ports in Java, Bali, and Sulawesi as defense against European attack (Reid 1993b:87-88). This wall could also have been a vestige of the "Portuguese fort," the ruins on which the Dutch builders of Fort Nassau said they laid their foundation stones in 1609 (Hanna 1978). While I have not found any record of a fort in Banda in the Portuguese documents, it is possible that what the Dutch thought was a ruined Portuguese fort was in fact an Asian-built structure. The fact that only Nera is shown with walls suggests that this settlement was a foreigner enclave, a conclusion also supported by the written account of this voyage. In other Southeast Asian ports, foreign traders often occupied defended compounds, some of which were like self-contained cities themselves, complete with a mosque (Reid 1993b:86).

The next map under consideration, the Eridia $\operatorname{Map}^{2}$ (Fig. 3), is the most detailed depiction of settlements in Banda from the Portuguese viewpoint (see Cortesão and Mota 1987: pl. 271, 285 for additional examples). In 1602, Jacob van Heemskerk (the commander of the first Dutch fleet under van Neck that reached Banda in 1599) captured a small Portuguese vessel returning from Ambon that was carrying this map of Banda, as well as other documents relating to a supposed trade contract between the Portuguese and the Bandanese (Leupe 1876). What is notable about this map is that (as with the van Neck Map) only the main trading settlements are shown: Nera, Labataca, and Lontor. This suggests 


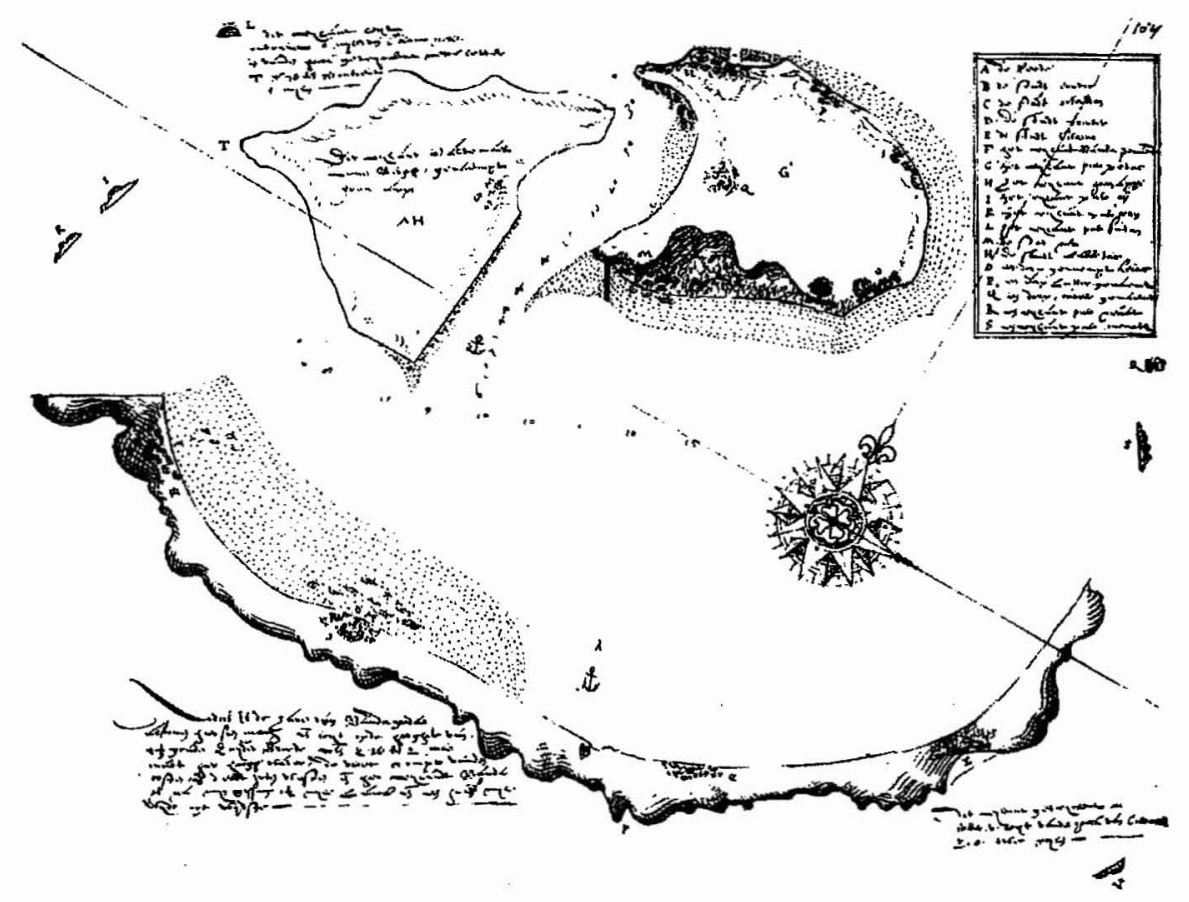

Fig. 4. Gelderland map (1602).

either that the Portuguese were unfamiliar with the smaller, less trade-oriented settlements; they thought these smaller settlements unimportant; or less likely that these towns were the only settlements on Banda at the time. This latter possibility is largely discounted by the archaeological data discussed below.

The Eridia Map gives an indication of the relative size or importance of the three settlements. The settlement of Lontor is named as the "capital" of the islands, and the anchorage is shown adjacent to it. In most subsequent maps, Nera is shown as the principal settlement, or largest town. This may represent a shift in trade networks, as the Muslim ethnic enclave in Nera captured an increasing proportion of trade by the end of the sixteenth century.

An interesting comparison can be made between this and the contemporaneous van Neck Map. The Eridia Map shows the outer islands of Rhun, Ay, and Hatta as close to their true size relative to Banda Besar and Banda Naira. This might suggest that Portuguese merchants had more familiarity with the geography of these outer islands, and may have been welcomed in these hinterlands, farther from an anti-Portuguese center in Nera (cf. Sá 1954b:15-18).

The Gelderland $\mathrm{Map}^{3}$ is one of two maps that were included in the logbooks of the Dutch ship the Gelderland. The Gelderland was the flagship of the fleet of the Wolfert Harmenszoon expedition to the Indies in 1601-1603, which was in Banda from April until June 1602. The two maps are stylistically distinct, though similar, and only one is signed (by Jooris Joostenszoon, the admiral's personal assistant), indicating that different mapmakers drew them. The signed map is the one reproduced here (Fig. 4). 
These maps are particularly useful. Since they are hand-drawn originals included in a ship's logbook, it appears that they were completed during actual visits, and were saved from error-prone changes by later engravers or publishers. The maps depict an unusual view of the islands, seemingly combining both profile and "birds-eye" views. As with the maps discussed above, the three central islands of Banda Naira, Banda Besar, and Gunung Api are shown in the most detail. This suggests, as does the account of this voyage, that the fleet did not visit other islands, nor the outer coast of Banda Besar. However, unlike the maps described above, this map is the earliest one to show smaller settlements and hamlets on Banda Naira and Banda Besar. Other clues abound in the inscriptions. While not explicitly ranked by size, settlements are nonetheless given different names that may correspond to their relative size or importance. The most important or biggest settlements are probably those called "towns" (stadt in Dutch) including Lontor, Cilamo, Nero and Labbetac, and Keinc. A second tier in size or importance would include "small town" (stedeken) including Orlatten, Comber, followed by the smaller "villages" (dorp in Dutch) including Latter and Ouver. Finally, there is an unnamed "hamlet" (vleck in Dutch) listed on the western end of Banda Besar, which may correspond to the settlement of Mandiango listed on some later maps. The second Gelderland map categorizes the settlements slightly differently (Lape 2000b:95-99).

In addition to naming and locating some of the smaller settlements on the inner islands, this map describes one settlement's political function ("a small town Ortatton where the general county meetings are held"). This gives a definite location for an important aspect of political structure in precolonial Banda. According to the Gelderland journals (and several other historical accounts), this was the place where the orang kayas of the various independent settlements would gather to discuss intervillage issues. It was also an important trading site, with a resident syahbandar or harbormaster. These maps also give some place names that later disappear from the records, and may have been older Bandanese language names that went out of common usage or were translated into Malay.

The Hermanszoon expedition was the first to draw up a written treaty or contract between certain settlement leaders and the VOC guaranteeing the Dutch exclusive trade and the Bandanese protection from their "enemies," including the Portuguese. The Gelderland Maps can be considered a crucial part of these political documents, though their importance may not have been fully appreciated by the people who drew them. One possible scenario is that certain settlements or islands that did not agree to sign the treaty were simply left off of the map, so that it would appear to officials in Amsterdam (or protesting English ambassadors) that the Bandanese were unanimous in their approval of it. Indeed, the fact that Pulau Rhun is never shown to have settlements on Dutch maps from the era when the English were well ensconced on that island may say something about the kinds of information deliberately withheld from these strategic documents ("Gelderlandt" 1603; see Lape 2000b:47-80 for extended discussion of relations between Dutch, English and Bandanese before 1621).

In summary, the Gelderland Map shows a large increase in the number of settlements on the inner islands from maps such as the van Neck Map or the Eridia Map made just two or three years earlier. The question is whether this is because new settlements were actually established in that short time, or (more likely) that 


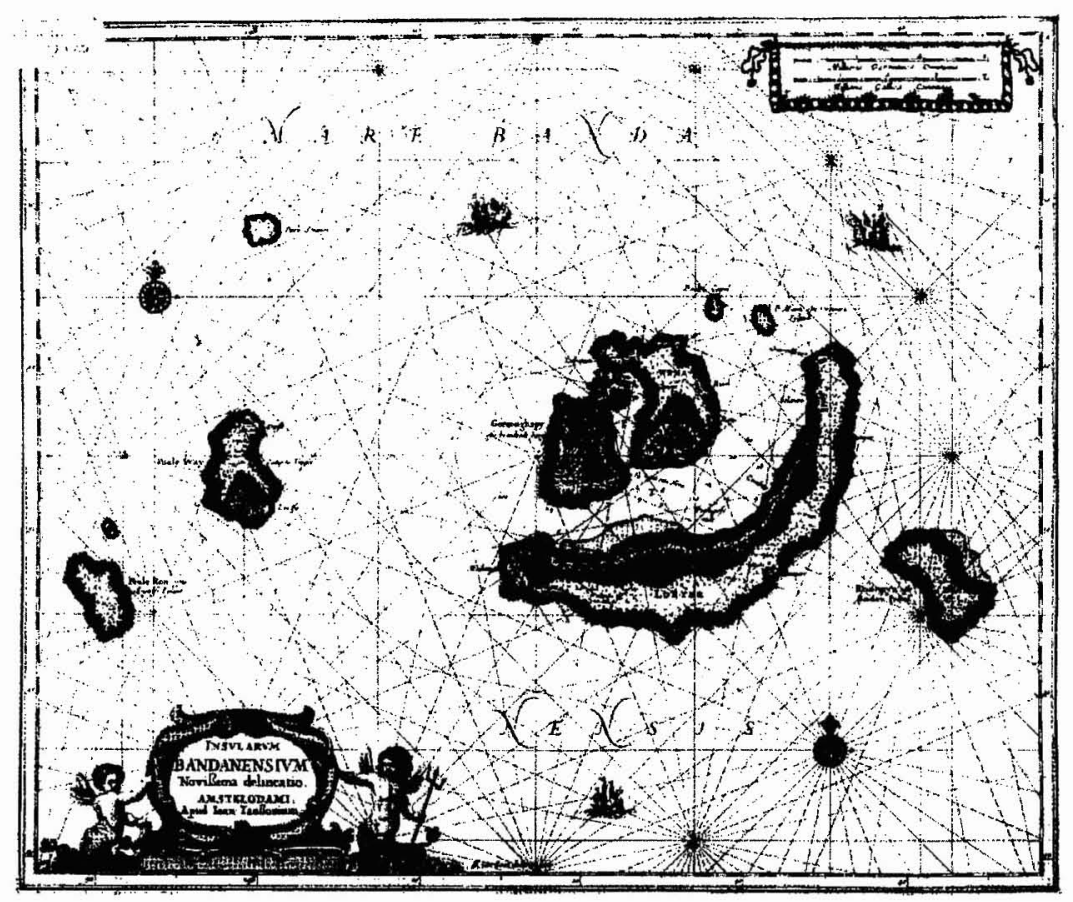

Fig. 5. Jansonnius map (1615).

earlier mapmakers did not see these settlements or considered them irrelevant or in opposition to their interests.

The Jansonnius Map ${ }^{4}$ provides a glimpse into Dutch representations of the islands circa 1615 (Fig. 5). While not published until 1633, it is based on the earlier Gerritsz Map (Zandvliet 1998:90), and the absence of Fort Revenge on Pulau Ay dates this map to pre-1616 (Lape 2000b:103-108; Zandvliet 1998:9598). This map provides the most detailed view of the preconquest Banda Islands on known and available maps in archives. Alternative names are given in addition to common names for some islands. Pulau Rhun is called "the English Island" (Engelse Eylant), Pulau Hatta, which is the least visible in the historical records, is intriguingly called "the bandit island" (Banditen Eyland), and Pisang (called Pulau Maon on this map, a preconquest name) is also named "women's island" (Vrouwen Eyland). No settlements are shown on Pulau Rhun, Hatta, or Gunung Api. However, many settlements are shown on Banda Besar, Banda Naira, and Pulau Ay. On Banda Besar, these include Combar, Selamon, Owendender, Wayer (as a settlement on the outer coast-not as an island near Labbetacca), Sammer, Leckovy, and Madiango. Interestingly, Lonthoir is shown (as a group of houses) but not named, although Banda Besar Island is named Lontor. Similarly, Naira is not named, though the island of Banda Naira is named Nera. This is a shift from island names on the Gelderland Map, which names Banda Besar simply "Banda" and Banda Naira "Pulo Potac." It appears that the names of these two islands had taken on the names of their two respective trading towns, perhaps signifying the increasing political dominance of these two towns, or perhaps a loss of indigenous 
identity to Javanese or Malay dominance. Another interesting feature of this map is the three settlements shown on Pulau Ay: Ditsa, Campong Timur, and Leytsa. This is the only map found, other than the Gerritsz Map, that shows more than one settlement on Pulau Ay. All post-conquest maps show only one settlement around the Dutch Fort Revenge, while other preconquest maps indicate no settlements at all. The curious thing about this map is the fact that the Dutch supposedly spent little time on Ay until the defeat of British-supported Bandanese forces on the island in April 1616, at which time the English fort was enlarged and strengthened and renamed Fort Revenge (Hanna 1978:41). Yet, this map shows several settlements and no fort. This would suggest that the Dutch had significant knowledge of Pulau Ay's settlement structure before they conquered the island, perhaps gained from Bandanese defectors or during previous unsuccessful Dutch attacks on the island.

The names of the settlements provide some possible clues about settlement patterns, while raising new questions. Campong Timor means "eastern town" in Malay. The meaning of timor ("east") is puzzling here. The settlement appears to be situated on the site of the present day village of Ay (on the north coast of the island) judging from landscape clues, such as the mountain in the southern end on the map. For this to be coherent with contemporary maps, the orientation of the island in the map would have to be turned 90 degrees counterclockwise (compare with Fig. 1, see Fig. 7 for one summary view). This north coast has the best access to the sea for larger boats and year-round monsoon protection, though there are no harbors on Ay, which is surrounded by either fringing reefs or high cliffs, usually a combination of both. The east coast of the island faces Banda Naira, but the coastline along this stretch is the most inaccessible on the island. The use of the Malay term campong indicates that this may have been an ethnic enclave, inhabited by Malay-speaking foreigners (Reid 1993b). The other two settlements, Leytsa and Ditsa, do not appear to be Malay words, and may be from the Bandanese language (Leytsa might be related to an Ambonese word for peninsula, lei). They are situated on strategic points on the coast, the eastern and western capes of the island (if we rotate the island to its "correct" orientation), which are well situated to view shipping coming in and out of the central Bandas and Pulau Rhun respectively. All three of these toponyms disappear from the record following the 1621 Dutch conquest. It is likely, given the relatively flat terrain and small size of Pulau Ay, that Dutch forces completely wiped out previous settlements and reinscribed the landscape according to colonial plans.

On Banda Besar, the settlements of Mandiango, Leckovy, and Sammer, on the southern coast, also eventually disappear from later maps, although they survive longer than the settlements of Pulau Ay. Mandiango appears on maps until the mid-seventeenth century before disappearing from the written records. It is probably Mandi Angin ("wind bath"), a name now used in oral traditions for a beach and area of sacred sites on the eastern headlands of Banda Besar. The name Lackovy also survives to this day as the name of bay (as Lakuy), and is shown as a village on maps of the later seventeenth century. Sammer disappears from maps as a settlement, but reappears on a mid-nineteenth-century Dutch map as an old name for the area around its previous location (oud land Sammer). It is also mentioned in Valentijn's late-seventeenth-century account of Banda as a trading partner with the Tanimbar Islands, though Valentijn may be referring to preconquest 


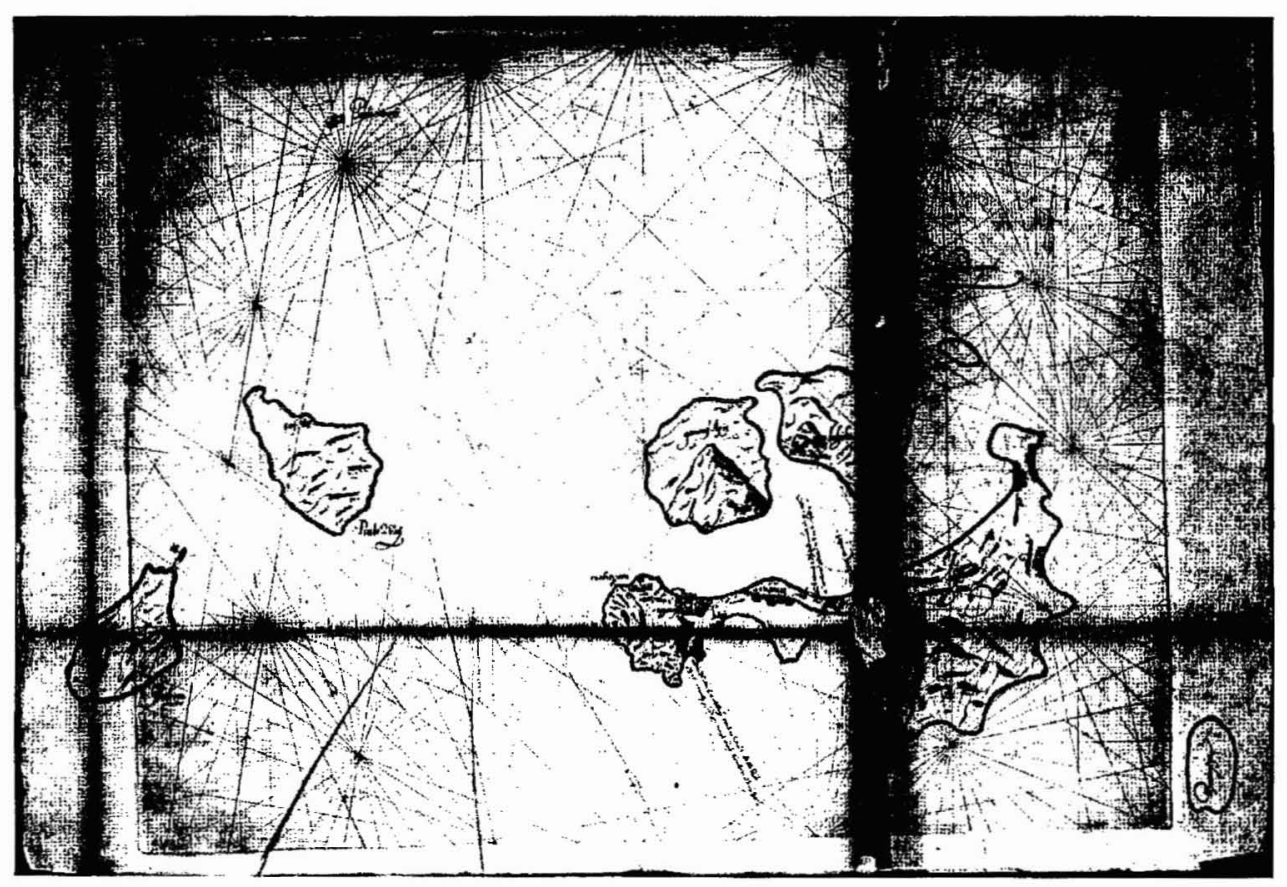

Fig. 6. Anonymous Dutch map (1623).

history (Valentijn 1858:29; for reproduction of Valentijn's 1724 map, see Suarez 1999:236).

Despite questions of accuracy in regions outside of firm Dutch control (such as Pulau Ay and Rhun), this map gives us the most detailed view of the settlements of the islands prior to the conquest of 1621. Many of the smaller settlements listed here disappear from maps just a few years later.

The conquest of Banda in 1621 was the beginning of a near total revision of Banda's social landscape. The Anonymous Dutch Map ${ }^{5}$ (Fig. 6) is dated 1623, which makes it the earliest surviving depiction of this new, post-conquest Banda. It is probably a VOC survey map, drawn by the recently victorious Dutch of their newly acquired (and ethnically cleansed) territory in Southeast Asia. The landforms are accurately portrayed, considerably improved from the Gerritsz and Janssonius Maps of just a few years earlier.

What is most striking on this map is the disappearance of many settlements. While the Dutch clearly now had the access necessary for accurate survey, it seems as though there were no longer small settlements in the hinterlands that they felt were worth noting. It is possible that there were pockets of Bandanese resistance that Dutch surveyors did not see because they were well hidden in the forests or mountains. Perhaps the Dutch refused to grace such rebel camps with the dignity of inclusion on an official VOC map. Most likely is that the map depicts the rapid depopulation of the islands as a result of the Dutch conquest. Pulau Ay is empty save an unnamed "fort." Banda Naira is also cleared of its many smaller settlements, leaving only Neira, and its two forts Nassau and Belgica. 
Banda Besar, on the other hand, retains many of its settlements, including Lontor, Ortattan, Selamon, Owendender, Wayer, Lackoey, and Mandiango. Banda Besar, it would appear, was the least altered of all the Banda Islands by the events of 1621 , perhaps because it had a relatively large population that was scattered over a mountainous landscape. Many of the surviving settlements are located on the south coast of the island that is difficult to access from the sea during the monsoons. A series of maps from the first half of the seventeenth century more clearly echoes the Dutch mindset about their new territory and the silence of the remaining Bandanese inhabitants: each island is shown devoid of most settlements, and is rather divided into plantation blocks, each listed with a number of "souls" (zielen) which were the number of slaves thought required to tend to the nutmeg harvest (Lape 2000b:115-116; Zandvliet 1998:154-155). Particularly striking in the Anonymous Dutch Map is the absence of Labbetacca, which appears on all previous maps, and was clearly an important settlement before the 1621 conquest. The fate of Labbetacca during and after the colonial conquest is one of the questions that will be addressed with the archaeological evidence below.

\section{CONCLUSIONS AND NEW QUESTIONS FROM HISTORIC MAPS}

As with any historical document, each map has its own set of biases that are based in the historical context of their drawing, publication, and distribution. Many of these biases are difficult or impossible to understand completely, and historic maps must be deconstructed rather than simply read (Harley 1992). However, it is possible to draw some general conclusions about precolonial Bandanese settlement from the maps, and to begin to cast the map data against the archaeological record.

The earliest detailed European maps of Banda from 1600-1603 show a small number of settlements only on the central Bandas: Labbetacca and Nera on Banda Naira, and Lontor, Ortattan, Combir, and Selamon on Banda Besar. No settlements are depicted on the outer islands of Rhun, Ay, and Hatta, or on the smaller islands of Pisang, Nailakka, Karaka, or Manukan. From 1603-1617, the maps show increasing numbers of settlements on Pulau Ay, the outer coast of Banda Besar, and the interior of Banda Naira. These "new" settlements are represented as smaller and less important than the settlements in the central Bandas (Fig. 7).

How do we interpret this change? There are two options: (1) these newly mapped settlements are in fact new settlements. Perhaps they represent a local response to European or other foreign influence, as they appear during a period of increasing tensions in Banda. Between 1609 and 1616, for example, Dutch and English forces built at least three new forts, the Verhoeven ambush took place, and numerous treaties were signed and defied. People in Banda could have been migrating to parts of the islands less subject to European control (Lape 2000b, $2000 c$ ). Indeed, the "new" settlements are located in areas out of sight of the forts and on coasts that are less accessible to boats; (2) These settlements may have existed all along, and were either not seen by the earlier European mapmakers, or considered unimportant by them. The primary European anchorages were in the protected waters of the inner Bandas, out of sight of the outer coasts and outer islands. The earlier European expeditions tended to stay in Banda for relatively shorter periods, and before mapmaking became a more institutionalized scientific 


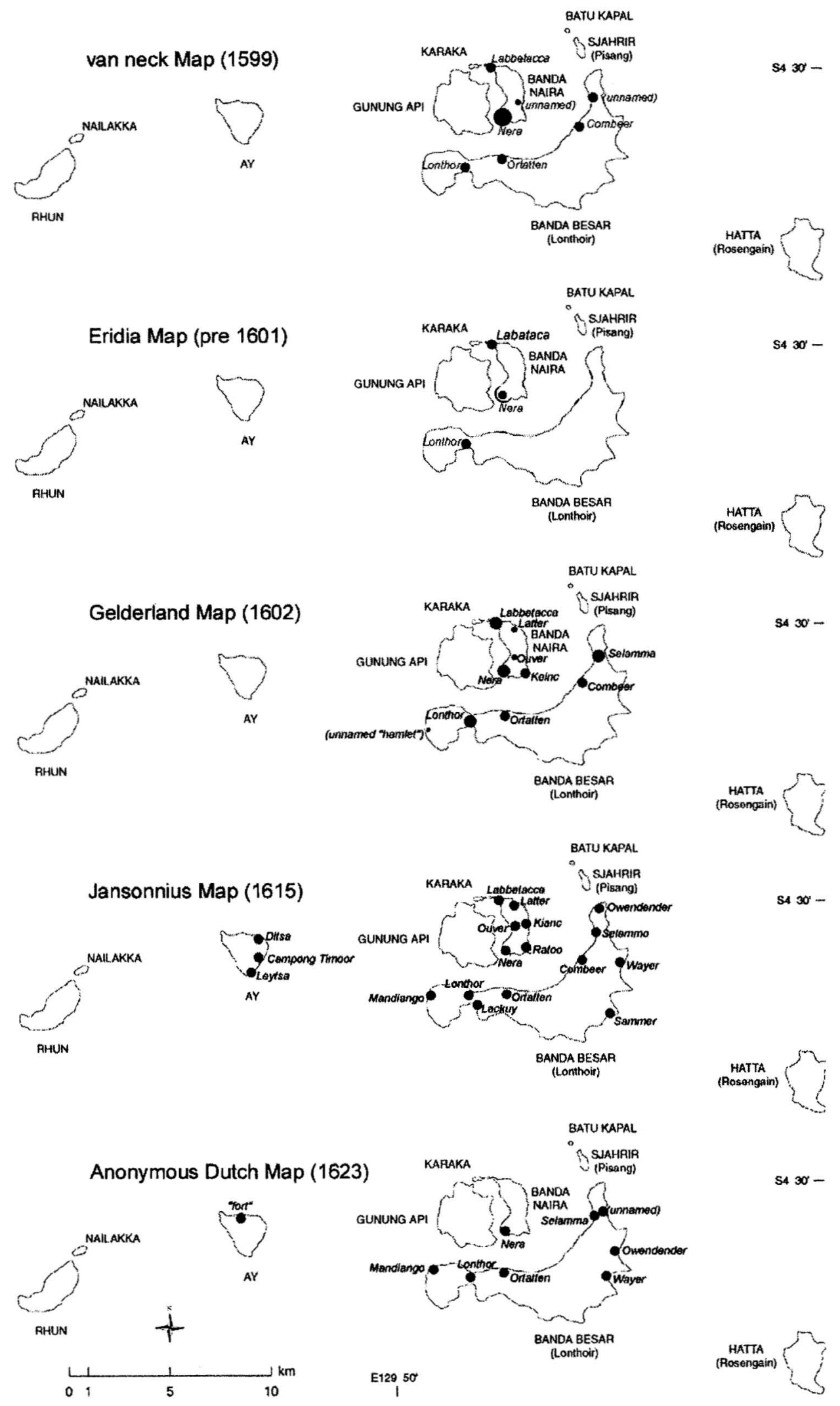

- settlement name and relative size as recorded on historic maps

Fig. 7. Settlement change as depicted on historic maps 1599-1623. Settlement sizes were differentiated only on the van Neck and Gelderland maps or associated texts. 
endeavor in the hands of the VOC, maps were seldom improved from voyage to voyage (Zandvliet 1998). The newer maps may simply represent different mapmaking objectives, rather than changing settlement patterns in Banda.

One important factor may have been the religious-political orientation of the settlements. There is substantial documentary evidence that the entrance of Portuguese traders into the East Indies caused social polarization around religious lines (e.g., Astley 1746:441; Birdwood and Foster 1893:492; Coen and Colenbrander 1919:470; Moreland 1934:89; Purchas et al. 1905:199; Sá 1954b; Sainsbury 1870:361). Muslim-oriented settlements had been increasingly more successful in attracting long-distance trade for several centuries before the first Portuguese arrival in Malacca in 1511. Portuguese efforts to control trade, and indigenous resistance to those efforts, were often framed by actors as a religious battle. Non-Muslim indigenous settlements were faced with a choice of aligning themselves with the Portuguese or with local or foreign Muslim leaders (Andaya 1993; Reid 1993a). In Banda, it appears as though local non-Muslim settlements were marginalized or forcibly converted, according to the heavily biased Portuguese accounts from the sixteenth century. Village alliances may have been constructed along religious boundaries (Jacobs 1970; Sá 1954a, 1954b; Villiers 1981). These theories can be examined archaeologically.

After the 1621 conquest, different questions arise. Why do many settlements disappear from maps, some immediately (Labbetacca), others fading away over a century (Mandiango)? In addition, why do others survive (Nera, Lonthoir, Selamon, Combir, Wayer), or are reborn centuries later, at least in name (Lackuy)? Clearly, the Dutch must have appropriated some preconquest names for their new plantations and towns (though altered in many cases, such as Labbetacca-Lautaka and Ortattan-Orangdatang). Nevertheless, some settlements never reappear in any form, such as the three preconquest settlements of Pulau Ay and the interior settlements of Banda Naira. These questions are fundamentally about the reliability of the historical data, and are therefore ones that archaeological data can potentially address. Below is a list of specific questions to be addressed using the available archaeological data.

1. Do the post-1603 maps (which show many previously unrecorded settlements) represent the establishment of actual new settlements, or the first European recognition of long existing settlements?

2. Can we see an archaeological correlate of conversion to Islam? If so, is there a link between patterns seen in historic maps and the religious orientation of the settlements?

3. How did the 1621 conquest affect settlement patterns?

4. How can we explain disjunctures between the documentary and archaeological data?

\section{ARCHAEOLOGICAL DATA}

The archaeological portion of my research in Banda was aimed at gathering data about social processes operating during a period of intense cross-cultural interaction. Research objectives were to collect chronological data on settlement pattern changes, and to investigate whether individual settlements were distinctive in terms of material markers of behavior and settlement history in the five centuries 
leading up to the conquest of the islands by VOC forces in $1621 .^{6}$ Archaeological survey, excavation, and most artifact analysis were conducted during two field seasons in 1997-98. A full-coverage settlement analysis was not attempted (cf. Fish and Kowalewski 1990), given the short time frame available and conditions that made systematic site survey impossible.

Rapid sediment deposition from the Gunung Api volcano has buried signs of older settlements with a thick layer of volcanic tephra, making sites difficult or impossible to see during pedestrian survey. The islands are generally either covered in dense vegetation or currently inhabited. Many of the late precolonial settlements very likely were reoccupied after the colonial conquest in 1621, and became the currently occupied towns existing today. In response to these limitations, I attempted to locate a reasonably large sample of different settlement locales dating to the late precolonial era through various strategies. A total of twenty sites (defined as places of archaeological interest) were discovered by these means and subjected to test excavations, with the objective of identifying those sites with late precolonial period remains (Fig. 1). Six sites had such remains, but due to time constraints, only four of those were excavated more extensively (BN1, BN2, BN4, and PA2), and these form the basis of this discussion. One additional site, PA1, was also excavated more extensively but dated to an earlier period (c. 3200 B.P.). Pedestrian survey was most productive on the outer island of Pulau Ay on land cleared for agriculture. About 50 percent of the land area on Pulau Ay was accessible for this type of survey, and sites discovered on the island (excluding PA2 and PA3, which are in a village) were located through the presence of surface remains such as pottery. In currently occupied towns, sites were located through nonsystematic subsurface testing in areas where we could obtain local permission and which had reasonable security, such as the walled garden areas of Dutch colonial houses (sites PA2, PA3 and BB4, BB5, and BB6). Some sites were discovered because shoreline erosion had revealed older deposits in wave-cut banks (such as site BN1). Site BN4, which was located on the sixteenthcentury shoreline, though now some $80 \mathrm{~m}$ inland inside the walls of the former VOC governor's house, was located through subsurface testing, guided by a series of eighteenth- and nineteenth-century colonial period maps that documented shoreline progradation on southern Banda Naira. A limited experiment allowing local oral historians to guide site selection on Banda Besar was not archaeologically productive, although local informants often directed us to surface remains on Pulau Ay.

Cultural deposits were primarily midden deposits, composed of ceramics, metal, and faunal remains. Sites on Banda Naira and Banda Besar were clearly stratified due to the regular deposition of culturally sterile volcanic tephra. In some cases, these tephra lenses could be linked to historically recorded volcanic eruption episodes. Excavation strategy was oriented to obtaining chronological data using small (1-by-1 and 2-by-2 m) isolated block units, for a total of four $11 \mathrm{~m}^{2}$ areas of excavation per site. Test pits were used to identify site boundaries, and units were interspersed evenly across the site area, subject to the limitations of current use and geography of the sites. Generally, the built environment and intrasite structure remains poorly understood, though evidence for stone structures was encountered in some cases (see Lape $2000 \mathrm{~b}$ for details of archaeological research design and results). As is apparent, the archaeological data collected 


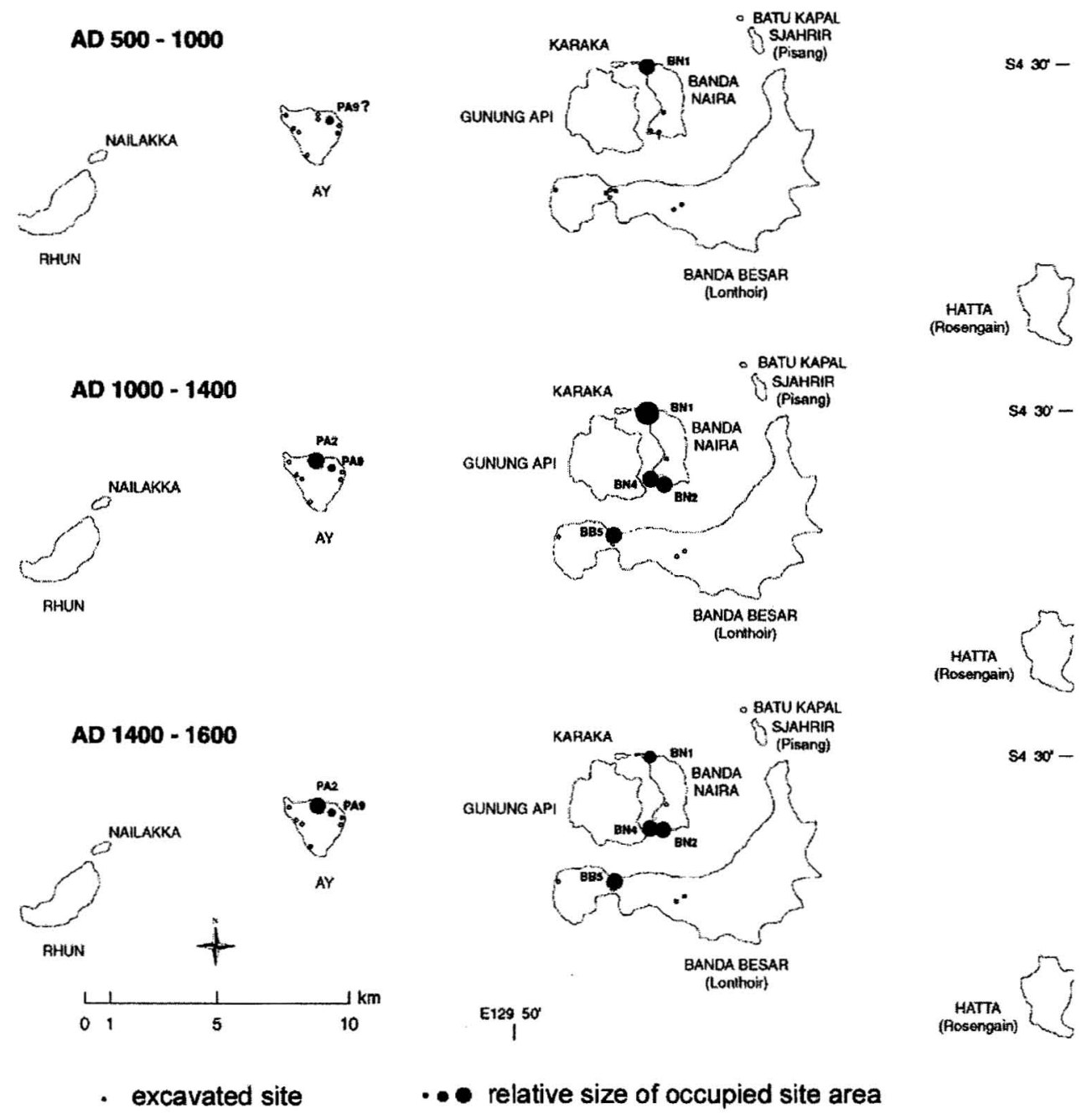

Fig. 8. Archaeological settlement pattern change in the Banda Islands, A.D. 500-1600 as evident from excavated and dated sites.

should not be considered a representative sampling of human use of the islands over time and space, and it is likely that conclusions about individual site use will change as larger areas are tested. However, the sites that were tested archaeologically do provide information about dates of occupation and abandonment, changes in settlement area, trade goods, and foodways that allow at least a preliminary view of settlement patterning. These data are organized (Fig. 8) into three temporal periods: A.D. 500-1000, A.D. 1000-1400, and A.D. 1400-1600. Strata were dated with a series of radiocarbon dates (Table 1), and cross-checked with datable Chinese ceramic tradeware assemblages.

Settlement chronology for these four sites is as follows: Site BN1 was initially occupied by A.D. 500, and the presence of Chinese glazed ceramics (of Song or pre-Song era) in early strata suggest that the settlement had long-distance trade 
Table i. Radiocarbon Dates from Banda Island Sites

\begin{tabular}{|c|c|c|c|c|c|}
\hline $\begin{array}{l}\text { SAMPLE } \\
\text { NUMBER }\end{array}$ & LAB NUMBER* & SAMPLE MATERIAL & $\begin{array}{c}{ }^{13} \mathrm{C} /{ }^{12} \mathrm{C} \\
\text { RATIO }\end{array}$ & $\begin{array}{c}{ }^{14} \text { C AGE B.P. } \\
\text { UNCALIBRATED } \\
1 \text {-SIGMA }\end{array}$ & $\begin{array}{l}\text { DATE B.C./A.D. } \\
\text { CALIBRATED } \\
\text { 2-SIGMA** }\end{array}$ \\
\hline BN1-3-195 & AA-33114 & Animal bone & -20.8 & $1,370 \pm 60$ & A.D. $562-775$ \\
\hline BN1-4-178 & AA-34334 & Animal bone & -27.4 & $630 \pm 45$ & A.D. $1292-1402$ \\
\hline BN1-4-254 & Beta-115986 & Charcoal & -27.0 & $880 \pm 40$ & A.D. $1035-1250$ \\
\hline BN2-2-210 & AA-34333 & Marine shell & 0.8 & $800 \pm 45$ & A.D. $1160-1290$ \\
\hline BN4-1-240 & AA-33118 & Marine shell & 2.8 & $900 \pm 65$ & A.D. $1022-1249$ \\
\hline BN4-2-246 & AA-33119 & Wood & -25.1 & $435 \pm 45$ & A.D. $1409-1625$ \\
\hline PA1-1-50 & AA-33117 & Animal bone & -22.5 & $3150 \pm 180$ & 1871-927 в.C. \\
\hline PA1-1-130 & AA-33116 & Animal bone & -19.1 & $2870 \pm 60$ & $1257-899$ в.С. \\
\hline PA2-2-125 & AA-33120 & Charcoal & -27.0 & $410 \pm 45$ & A.D. $1423-1632$ \\
\hline
\end{tabular}

Note: Samples BN1-3-195, BN2-2-210, and BN4-2-246 are from the lowest excavated strata in their respective sites.

* AA: NSF-University of Arizona AMS Facility; Beta: Beta Analytic.

** Calibrated using University of Washington Quaternary Isotope Lab Calib 4.1.2 (1999).

contacts, although these were sporadic until A.D. 1100-1200. The site appears to have been abandoned by A.D. 1600-1700. It appears to coincide with the historically known village of Labbetacca. The Dutch perek (plantation) called Lautaka is located a short distance away from the site, and it appears that the Dutch appropriated this village name for their plantation, which has now become the name of a small hamlet contained by the garden walls of the perek. Site BN4 was first occupied at approximately A.D. 1000-1100, and the nearby site BN2 by A.D. 1300 . Both of these sites were continuously occupied into the colonial period (although by different social groups), and both appear to coincide with the historically known village of Nera, now the town of Naira. Site PA2 was first occupied by A.D. 1300 , and also saw continuous occupation through the colonial period to today, and is within the contemporary village of Ay (see Fig. 9 for a timeline representation of these four sites).

All of these sites contained large quantities of long-distance trade goods, with glazed ceramics from Mainland Asia appearing in the oldest strata of all four sites. Site BN1, however, is distinctive in several ways. It was initially occupied before the others, and is the only one that was abandoned by the early colonial period. It was located in a different geographical situation compared with the others, with an exposed, unprotected beachfront surrounded by high bluffs, whereas the other sites are on flat coastal planes with protected harbors. BN1 also has distinctive late precolonial archaeological assemblages. The site has dense deposits of a distinctive sculpted earthenware pottery found nowhere else in Banda, dating from A.D. 500-1600, based on associated radiocarbon-dated materials (Lape 2000c:143). Only at site BN1 is there evidence for human cremation burials, with burned fragmented human bone and teeth, and only site BN1 shows evidence for pig consumption in the late precolonial period. All other late precolonial sites lack pig bones and teeth in faunal assemblages.

Let us return now to the questions posed by the analysis of historic maps.

1. Do the post-1603 maps (which show many previously unrecorded settlements) represent the establishment of actual new settlements, or the first European recognition of long- 


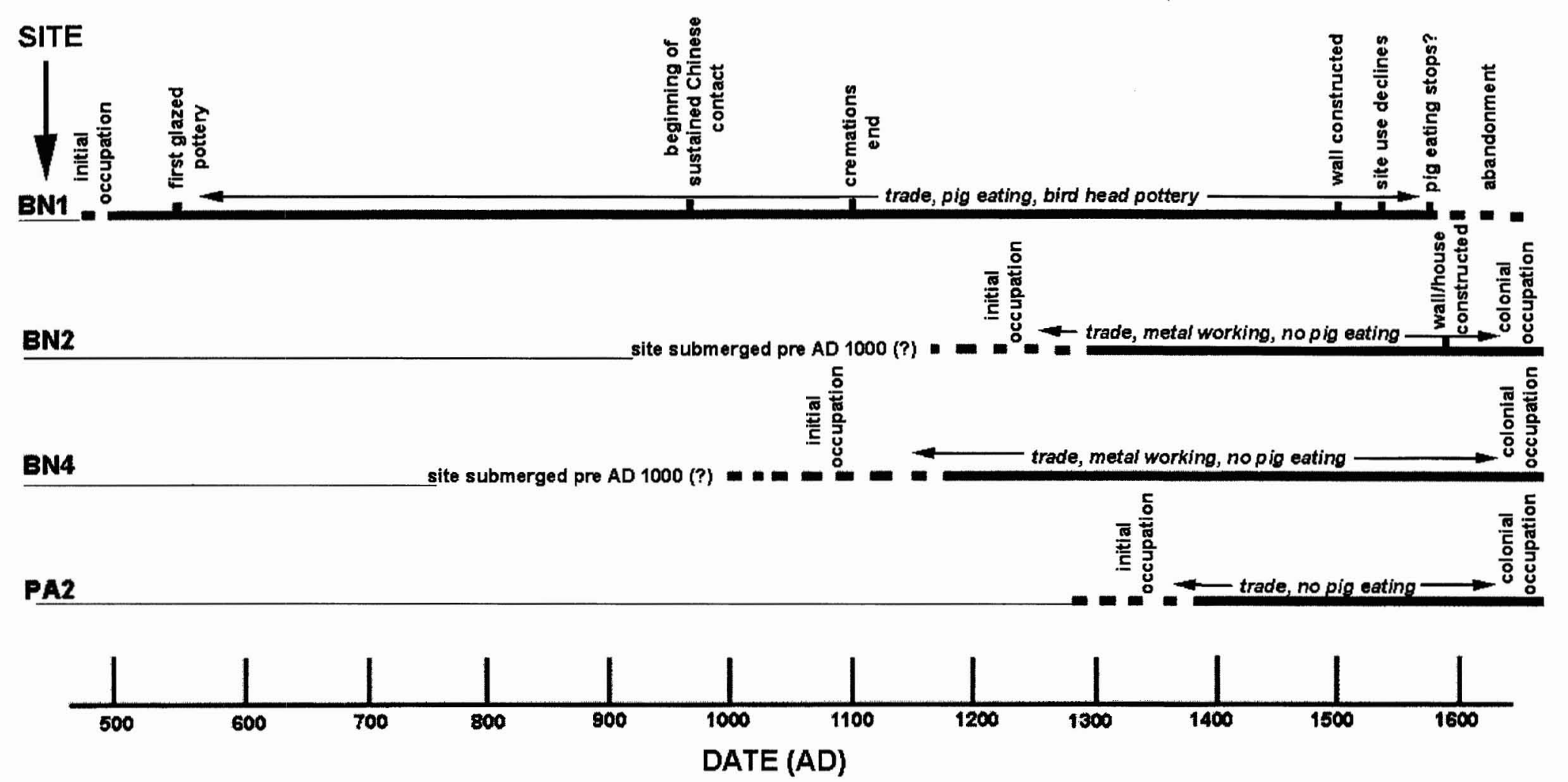

Fig. 9. Occupation timeline of archaeological sites BN1, BN2, BN4, and PA2. 
existing settlements? On Pulau Ay, site PA2 (possibly Campong Timor on the Jansonnius Map) was continuously occupied from A.D. 1300 though the colonial period to the present. Site PA9 (possibly the settlement of Ditsa or Leytsa noted on the Jansonnius Map) was probably inhabited from well before A.D. 1500 due to the presence of earthenware pottery containing strata underlying strata containing Ming-era ceramics. The existence of settlements on Ay, which were not depicted by European mapmakers until after 1615, calls into question the reliability of earlier maps, particularly regarding the outer islands and outer coast of Banda Besar. There is no archaeological or documentary evidence that suggests these new settlements were suddenly established after 1603. I believe it is likely that Dutch and Portuguese mapmakers either lacked information about settlements on Pulau Ay, or deliberately left them off maps because their allegiance to the European powers was questionable or nonexistent. This is one question that additional archaeological research can confirm.

2. Can we see an archaeological correlate of conversion to Islam? If so, is there a link between patterns seen in historic maps and the religious orientation of the settlements? Besides the Neolithic site PA1, only site BN1 (coinciding with the settlement of Labbetacca listed on all pre-1621 maps) had material evidence of non-Islamic behavior, such as pig eating and cremations. Cremations appear to end by the twelfth century, which would be at least three centuries earlier than expected for a shift to Islamic burial practices in Banda. Pig eating also ends, but with the existing evidence, it was impossible to date this shift more precisely than the 300year period between A.D. 1300 and 1600. The abandonment of pig eating at this site may coincide with its depopulation after the 1621 conquest, and subsequent repopulation by Muslim slaves brought by the Dutch from other parts of South and Southeast Asia. If however pig eating were abandoned before 1621, it would be highly suggestive of a change due to religious conversion of the native inhabitants of the site. Additional excavations at site BN1 oriented towards a better understanding of site use and stratigraphy may allow us to confirm one of these possibilities.

Turning back to the documentary evidence, historical descriptions of precolonial Labbetacca are inconclusive about the religious orientation of its inhabitants. However, there is considerable circumstantial evidence that suggests a non-Islamic orientation, or possibly a different ethnic expression of Islam as compared with other places in Banda. Chief among them is the titles used by leaders of the villages that appear on various treaties and agreements with Europeans. In these documents, Labbetacca leaders never include the titles Imam or Syahbandar, Muslim titles that were used by leaders of every other village listed in treaty documents (Ellen 1986; Lape 2000b: 76-80).

The absence of pig remains at all late precolonial sites in Banda besides BN1 suggests the possibility that Muslims were the colonizers of these settlements. The data may be the result of sampling error (because of the relatively small area excavated), and there may be other explanations for the lack of pig remains at these sites, however, the differences seen thus far are unequivocal. This interpretation would put Muslim presence in Banda rather earlier than generally accepted, as historical documents suggest a mid-fifteenth-century conversion in Banda (Pires and Rodrigues 1944; see also Lape 2000b, 2000c for an extended discussion of Islam in Banda). If we consider the possibility that BN2, BN4, BB5, 
and PA2 were occupied not by Bandanese, but by visiting Muslim long-distance traders, the early dates for Islamization might be more acceptable (see early dates for Muslim presence in other parts of Indonesia in Hall 1981:221-225 and references to Banda in early Arab texts, Tibbetts 1979). In any case, the distinctive BN1 assemblage suggests that the process of Islamization in Banda was not allencompassing and instantaneous, but affected different settlements at different times. As discussed in other publications (Lape 2000a, 2000b, 2000c), sixteenthand early-seventeenth-century documents also suggest that this uneven Islamization process caused significant conflict within Bandanese society, and that European colonizers were able to use these internal divisions to their advantage in the colonial conquest.

3. How did the 1621 conquest affect settlement patterns? All archaeological sites showed significant changes in post-sixteenth-century strata, primarily the introduction of European artifacts, such as kaolin tobacco pipes. Historical data do suggest that most settlements were probably immediately repopulated with Dutch and other Asians after the conquest, and there is archaeological evidence that the new occupants had different foodways, because pig and cow bones appear in most colonial period faunal assemblages. Here again site BN1 looks different from other sites. BN1 colonial period faunal assemblages are mostly fish, and lack pig and cow bones. This suggests a non-Dutch occupation, perhaps an Asian (Mus$\mathrm{lim}$ ) slave settlement, or a settlement of surviving native Bandanese. It shows signs that it was largely abandoned sometime in the mid-colonial period and is currently unoccupied. ${ }^{7}$ Site BN4 on the other hand had large amounts of colonial period remains, reflecting its use as the VOC governor's residence. BN2, PA2, and BB5 were all also at the center of colonial settlements, which have been continuously occupied up to the present.

4. How can we explain disjunctures between the documentary and archaeological data? Researchers who use both archaeological and documentary data are often faced with two primary challenges. The first is what Wilson (1993) has characterized as the problem of "mixed epistemologies," where each line of evidence has different accepted modes of explanation. Second is the problem of temporal scale; archaeological data typically have a temporal resolution of 50-100 years at best, and historical questions often require greater precision. Even if these first two challenges are met, there remains the possibility that the different data sets disagree, leaving the researcher to choose between them. However, the places where the lines of evidence disagree often expose new biases and allow for a more nuanced understanding of the processes that created the data. I believe that the questions posed here allow for these challenges to be met, if not overcome.

The archaeological data suggest that there were more settlements in Banda than depicted on pre-1603 maps, and that they were not newly established between 1603 and 1615. The settlements missing from the earlier maps but existing archaeologically were located on Pulau Ay, far from the trade centers of Lonthoir, Nera, and Labbetacca. It is likely that archaeological evidence for other "silent" settlements could be found on other remote places. The disappearance of Labbetacca from post-conquest maps, though, is corroborated archaeologically with the abandonment of site $\mathrm{BN} 1$. In this case, mapmakers had no reason to "hide" evidence of the success of the colonial project, the conquest and ejection of native Bandanese inhabitants. 
In some cases, the two data sets do not disagree, but rather serve to illuminate each other. The precolonial archaeological evidence from site BN1 or Labbetacca suggests that it was a non-Muslim-oriented settlement, with a much longer occupation history than the Muslim-oriented trade settlements of Nera and Lonthoir. Labbetacca may have been one of the first Banda settlements oriented to longdistance trade, which in the late precolonial era was in the process of losing influence to new better-situated ports. Unlike the other precolonial trade centers like Lonthoir and Nera, this site did not become a colonial center. One interpretation might be that the economic structures and geographical position that made BN1 a favorable trade site in the earliest era of long-distance trade with China no longer applied as trade networks shifted to the Muslim trading world. During the research process, the distinctive archaeological signature of site BN1 prompted me to look for distinctiveness in the documentary record. Patterns in leadership titles and village alliances emerged from this directed reading that I may have otherwise overlooked.

\section{CONCLUSIONS}

This study has demonstrated how historic maps and archaeological data can be used together to understand changes in settlement patterns as a result of crosscultural interaction. In this case, the utility of biased and incomplete data from these sources is extended through a process where each body of data is used to generate questions and as a testing reference. Ultimately, maps depict and represent both intentional and unintentional concepts of human geography held by mapmakers, and thus require careful analysis of the context of their production and intended audience.

By helping to identify human presence on the landscape that mapmakers did not depict on their maps, archaeological data from the Banda Islands late precolonial and early colonial periods has helped identify specific ways that Europeans understood and represented the landscape. These conceptions had political and social implications during the last decades of the precolonial era. The two bodies of evidence together suggest a significant division of Bandanese society that may have followed religious-ethnic lines. Europeans appear to have had more contact and trade relationships with Muslim-oriented settlements, despite the prevailing opposition to Islam that characterized the European colonial project in the East Indies.

Historians have generally agreed that the Bandanese resisted European efforts to control their trade, and were massacred and banished from their homeland as a result (Hanna 1978; Masselman 1963; van der Chijs 1886; Villiers 1981, 1990). Their resistance efforts failed because they were a small, under-armed polity in the way of the inevitable progress of European merchant capitalism and colonial empire building. However, these conclusions are based on a reading of a slim and European-biased body of textual evidence, which cannot account for internal social forces that factionalized and fragmented social and political organization in Banda. The archaeological data gathered from Banda's landscape reveal pasts and presents which visiting observers failed to notice. 


\section{ACKNOWLEDGMENTS}

Research in Banda was sponsored by Lembaga Ilmu Pengetahuan Indonesia (LIPI), Jakarta and Universitas Pattimura, Ambon, with permission from the Pusat Penelitian Arkeologi Nasional, Jakarta and Ambon, and the Direktorat Perlindungan dan Pembinaan Peninggalan Sejarah dan Purbakala, Jakarta, as well as the Maluku provincial and local Banda governments. Brown University, Earthwatch Institute, Garuda Indonesia Airlines, a Fulbright Fellowship, a National Science Foundation Dissertation Improvement Grant, and a Luce Foundation Fellowship supported archaeological fieldwork, analysis, and archival research. Isabel Rodrigues, Jaap and An Keppel, E. M. Beekman, Adriaan C. de Jong, Peter Veth, Vincent Loth, Manuel Lobato, and Nick Burningham provided guidance in the archives, translations, and historical insights. Many thanks to Miriam Stark, Ann Stahl, and three anonymous reviewers for their helpful critiques.

\section{NOTES}

1. The van Neck Map reproduced here is a photograph of an original obtained from the French language illustrated account of the van Neck voyage held in the British Library: Le second livre, Journal ov comptoir, contenant le vray discovrs et narration historique, du voyage fait par les huit navires Amsterdam, au mois de Mars Jan 1598, sous la conduite de l'Admiral Jaques Cornille Nec, E du ViceAdmiral Wibrant de Warwic. Amsterdam 1609. I also reviewed an English language version of this account, published in London in 1601, and the Dutch language version, which was reprinted by the Linschoten Society in 1942. The Schley Map was reviewed at the Universiteitsbibliotheek (Leiden University Library, Netherlands) Collectie Bodel Nijenhuis cat \#P.59 N.143. Copies reviewed of the Vicenzo Mario Cornelli Map and the Prevost Map are from the author's private collection.

2. This copy of the Eridia Map obtained at the Algemeen Rijksarchief, The Hague, microfilm cat \#4.VEL.245.

3. This copy of the Gelderland Map from Het Gelderlandt Journaal 1601-1603, ARA 135, Algemneen Rijksarchief, The Hague, Netherlands. Adriaan C. de Jong transcribed and translated the inscriptions on these maps. Nick Burningham of the Duyfken Foundation kindly passed reproductions of these maps on to me.

4. The Jansonnius Map is from Janssons's Atlas, this reproduction obtained from Universiteitsbibliotheek (Leiden University Library) Collectie Bodel Nijenhuis, P. 59 N. 138. A nearly identical map was published by Shenk and Valk, and is in the same collection in Leiden catalogued P.59 N.139.

5. This copy of the Anonymous Dutch Map obtained from the Algemeen Rijksarchief, The Hague, microfilm cat \#4.VEL.1355.

6. Evidence for human occupation dates to 3200 B.P. (at site PA1); pre-A.D. 500 settlement is discussed in Lape $2000 b$.

7. Precolonial BN1 appears to coincide with the settlement of Labbetacca shown on all precolonial maps. After conquest, however, a settlement called Lautacca or Lautaka appears in the same vicinity, and there is a small settlement called Lautaka today which lies about $400 \mathrm{~m}$ north of $\mathrm{BN} 1$, on a small isthmus. Unfortunately, the elders of this village would not give permission to conduct test excavations within it, so it was impossible to check whether this area was also inhabited in the precolonial era (see Lape $2000 b$ for a detailed discussion).

\section{REFERENCES CITED}

Abdurachman, P. R.

1978 Moluccan responses to the first intrusions of the west, in Dynamics of Indonesian History, ed. H. Soebadio and C. A. d. Marchie. New York: North Holland Publishers.

ANDAYA, L.

1991 Local trade networks in Maluku in the 16th, 17th, and 18th centuries. Cakalele 2(2):7196.

1993 The World of Maluku: Eastern Indonesia in the Early Modern Period. Honolulu: University of Hawai'i Press. 
"ANSWER"

1971 An answer to the Hollanders Declaration, concerning the Occurents of the East India, written by certain mariners, lately returned from thence into England. Reprint of 1622 ed. Amsterdam: De Capo Press.

ARgensola, B. L. D.

1708 The Discovery and Conquest of the Molucco and Philippine Islands. Facsimile version, published 1982. Ann Arbor, Michigan: University Microfilms.

Arthus, G.

1628 Historia India Orientalis: Ex variis auctoribus collecta, et iuxta seriem topographicam regnorum, prouinciarum \& insularum, per Africa, Asia que littora, ad extremos usque Iaponios deducta. Sumptibus VVilhelmi Lutzenkirch., Coloniae Agrippinae.

Astley, T.

1746 New General Collection of Voyages and Travels; vol. 1: Voyages of the English to the East Indies. London.

Ballard, C.

1987 Dudumahan: A rock art site on Kai Kecil, southeast Moluccas. Indo-Pacific Prehistory Association Bulletin 8:139-161.

BARBOSA, D.

1921 The Book of Duarte Barbosa: An account of the countries bordering on the Indian Ocean and their inhabitants. Trans. M. L. Dames, 2nd ser., no. 49. London: Hakluyt Society.

Bellwood, P.

199835,000 years of prehistory in the northern Moluccas, in Perspectives on the Bird's Head of Irian Jaya, Indonesia: 233-275, ed. J. Miedema, C. Odé, and R.A.C. Dam. Amsterdam: Rodopi.

BirdwoOd, G.C.M., AND W. Foster

1893 The Register of Letters, Ec., of the Governour and Company of Merchants of London Trading into the East Indies, 1600-1619. London: B. Quaritch.

Blussé, L.

1986 Strange Company: Chinese Settlers, Mestizo Women, and the Dutch in VOC Batavia. Verhandelingen van het Koninklijk Instituut voor Taal-, Land- en Volkenkunde no. 122. Dordrecht, Holland, and Riverton, U.S.: Foris Publications.

Bohigian, G. M.

1994 Life on the Rim of Spain's Pacific-American Empire: Presidio Society in the Molucca Islands, 1606-1663. Ph.D. dissertation, University of California, Los Angeles.

Chaudhuri, K. N.

1990 Asia Before Europe: Economy and Civilisation of the Indian Ocean from the Rise of Islam to 1750. Cambridge: Cambridge University Press.

Coen, J. P., and H. T. Colenbrander ed.

1919 Jan Pietersz. Coen: Bescheiden omtrent zijn bedrijf in Indië. 's-Gravenhage: M. Nijhoff.

Cortesão, A., And A. T. D. Mota

1987 Portugaliae Monumenta Cartographica. Lisboa: Imprensa Nacional-Casa da Moeda.

Cusick, J. G., ED.

1998 Studies in Culture Contact: Interaction, Culture Change and Archaeology. Occasional Paper No. 25. Carbondale: Center for Archaeological Investigations, Southern Illinois University.

"Description"

1598 The Description of a Voyage Made by Certain Ships of Holland into the East Indies, with their Adventures and Successe, April 1595-Aug 1597. Trans. t. f. t. D. b. W. Phillip. London.

Ellen, R. F.

1986 Conundrums about panjandrums: On the use of titles in the relations of political subordination in the Moluccas and along the Papuan coast. Indonesia 41:46-62.

Ellen, R. F., AND I. C. Glover

1974 Pottery manufacture and trade in the Central Moluccas: The modern situation and the historical implications. Man (n.s.) 9:353-379. 
FISH, S. K., AND S. A. KowALEwSKI

1990 The Archaeology of Regions: A Case for Full-Coverage Survey. Washington, D.C.: Smithsonian Institution Press.

Fisher, R., AND H. Johnston, EDs.

1993 From Maps to Metaphors. Vancouver: University of British Columbia Press.

Galloway, P. K.

1995 Choctaw Genesis, 1500-1700. Indians of the Southeast. Lincoln: University of Nebraska Press.

"GelDERLANDT"

1603 Het Gelderlandt Journaal 1601-1603, in Algemeen Rijksarchief. The Hague.

GoOdman, T.

1998 The sosolot exchange network of eastern Indonesia during the seventeenth and eighteenth centuries, in Perspectives on the Bird's Head of Irian Jaya, Indonesia: 421-454, ed. J. Miedema, C. Odé, and R.A.C. Dam. Amsterdam: Rodopi.

HALL, D.G.E.

1981 A History of South-East Asia. London: Macmillan.

Hall, $M$.

2000 Archaeology and the Modern World: Colonial Transcripts in South Africa and the Chesapeake. New York: Routledge.

HANNA, W. A.

1978 Indonesian Banda: Colonialism and its Aftermath in the Nutmeg Islands. Philadelphia: Institute for the Study of Human Issues.

Harley, J. B.

1992 Deconstructing the map, in Writing Worlds: Discourse, Texts, and Metaphors in the Representation of Landscape: 231-247, ed. T. J. Barnes and J. S. Duncan. London, New York: Routledge.

Harley, J. B., AND D. WoOdward

1987 Cartography in Prehistoric, Ancient, and Medieval Europe and the Mediterranean. The History of Cartography 1. Chicago: University of Chicago Press.

Harvey, M., and B. P. Holly

1981 Themes in Geographic Thought. New York: St. Martin's Press.

INSOLL, T.

1999 The Archaeology of Islam. Oxford: Blackwell.

JACOBS, H.

1970 A Treatise on the Moluccas (c. 1544). Probably the preliminary version of Antonio Galvao's lost Historia das Molucas. Sources and Studies for the History of the Jesuits, vol. 3. Rome: Jesuit Historical Institute.

Kirch, P. V., AND M. Sahlins

1992 Anahulu: The Anthropology of History in the Kingdom of Hawaii, vol. 2: The Archaeology of History. Chicago: University of Chicago Press.

LAPE, P. V.

$2000 a$ Contact and colonialism in the Banda Islands, Maluku, Indonesia. Bulletin of the IndoPacific Prehistory Association 20(4): 48-55.

$2000 \mathrm{~b}$ Contact and Conflict in the Banda Islands, Eastern Indonesia, 11th-17th Centuries. Ph.D. diss., Brown University.

$2000 c$ Political dynamics and religious change in the late pre-colonial Banda Islands, Eastern Indonesia. World Archaeology 32(1).

LEIRISSA, R. Z.

1978 The Dutch trading monopolies, in Dynamics of Indonesian History: 190-206, ed. H. Soebadin and C. A. d. Marchie. New York: North Holland Publishers.

1994 Changing maritime trade patterns in the Seram Sea, in State and Trade in the Indonesian Archipelago, ed. G. J. Schutte. KITLV Working papers No. 13. Leiden: KITLV Press.

LEUPE, P. A.

1876 Kaartje van de Banda-Eilanden ver-vaardigd door Emanoel Godinho de Eridia in 1601. Bijdragen tot de Taal-Land-en Volkenkunde 11(3):386-388. 
LINSCHOTEN, J. H. v.

1885 The Voyage of John Huyghen van Linschoten to the East Indies: From the Old English Translation of 1598. No. 71 ed. Vol. 1. 2 vols. London: Hakluyt Society.

Loth, V.

1995a Armed incidents and unpaid bills: Anglo-Dutch rivalry in the Banda Islands in the seventeenth century. Modern Asian Studies 29(4): 705-740.

1995b Pioneers and Perkeniers: The Banda Islands in the 17th century. Cakalele 6:13-35.

1998 Fragrant gold and food provision: Resource management and agriculture in seventeenth century Banda, in Old World Places, New World Problems: Exploring Issues of Resource Management in Eastern Indonesia, ed. S. Pannell and F. V. Benda-Beckmann. Canberra: Australian National University.

Marr, D., G. and A. C. Milner, eds.

1988 Southeast Asia in the 9th to 14th Centuries. Singapore: Institute of Southeast Asian Studies.

Masselman, G.

1963 The Cradle of Colonialism. New Haven: Yale University Press.

Meilink-Roelofsz, M.A.P.

1962 Trade and European Influence in the Indonesian Archipelago between 1500 and 1630. The Hague: Martinus Nijhoff.

MORELAND, W. H., ED.

1934 Peter Floris: His Voyage to the East Indies in the 'Globe,' 1611-1615. 2nd ser.; no. 74. London: Hakluyt Society.

Nakamura, $\mathrm{H}$.

1963 East Asia in Old Maps. Honolulu: East West Center Press.

Pires, T., AND F. Rodrigues

1944 The Suma Oriental of Tomé Pires, An account of the East, from the Red Sea to Japan, written in Malacca and India in 1512-1515, and The book of Francisco Rodrigues, rutter of a voyage in the Red Sea, nautical rules, almanack and maps, written and drawn in the East before 1515. Trans. A. Cortesão. Ser. 2, no. 89-90. 2 vols. London: The Hakluyt Society.

PTAK, R.

1998 Glosses on Wang Dayuan's Daoyi Zhilue, in China and the Asian Seas: Trade, Travel, and Visions of the Other (1400-1750): 127-141, ed. R. Ptak. Aldershot and Brookfield, Vermont: Ashgate.

1999 Asian trade in cloves, circa 1500: Quantities and trade routes-a synopsis of Portuguese and other sources, in China's Seaborne Trade with South and Southeast Asia, 1200-1750: 149-169, ed. R. Ptak. Aldershot and Brookfield, Vermont: Ashgate.

Purchas, S., and R. Hakluyt

1625 Purchas his Pilgrimes. In five books. 4 vols. Printed by William Stansby for Henrie Fetherstone, London.

Purchas, S., R. Hakluyt, and H. Society

1905 Hakluytus Posthumus, or Purchas his Pilgrimes: Contayning a history of the world in sea voyages and lande travells by Englishmen and others. Extra series (Hakluyt Society). 20 vols. Glasgow: James MacLehose and Sons.

REID, A

1988 Southeast Asia in the Age of Commerce, 1450-1680, vol. 1: The Lands Below the Winds. New Haven: Yale University Press.

1993a Islamization and Christianization in Southeast Asia: The critical phase, 1550-1650, in Southeast Asia in the Early Modern Era: Trade, Power, and Belief: 151-179, ed. A. Reid. Ithaca, New York: Cornell University Press.

19936 Southeast Asia in the Age of Commerce, 1450-1680, vol. 2: Expansion and Crisis. 2 vols. New Haven: Yale University Press.

RickleFs, M. C.

1993 A History of Modern Indonesia Since c. 1300. 2nd ed. London: Macmillan.

Rumpf, G. E., AND E. M. BeEKMAN

1981 The Poison Tree: Selected Writings of Rumphius on the Natural History of the Indies. Library of the Indies. Amherst: University of Massachusetts Press.

1999 The Ambonese Curiosity Cabinet. New Haven: Yale University Press. 
SÁ, A. B. D.

1954a Documentação para a História das Missões do Padroado Português do Oriente, Insulíndia, vol. 1. Agência Geral do Ultramar, Divisão de Publicações e Biblioteca, Lisboa.

$1954 b$ Documentação para a História das Missões do Padroado Português do Oriente, Insulíndia, vol. 4. Agência Geral do Ultramar, Divisão de Publicações e Biblioteca., Lisboa.

SAINSBury, W. N., ED.

1870 Calendar of State Papers, Colonial Series, East Indies, China and Japan, 1617-1621. London, Longman and Co.

SCHRIEKE, B.J.O.

1960 Indonesian Sociological Studies: Selected Writings. Selected studies on Indonesia by Dutch scholars; vol. 2. Bandung: Summur Bandung.

SChurhammer, G.

1962 Die Zeitgenossischen Quellen zur Geschichte Portugiesisch-Asiens und seiner Nachbarlander (Ostafrika, Abessinien, Arabien, Persien, Vorder- und Hinterindien, Malaiischer Archipel, Philippinen, China und Japan) zur Zeit des Hl.Franz Xaver (1538-1552). Unveranderter Neudruck der 1. Aufl. mit vollstandigem Index und Supplement bis 1962; ed. Georg Schurhammar, 1882, Gesammelte Studien; v. 1. Institutum Historicum S.I., Rom.

Sollewijn Gelpke, J.H.F.

1995 Alfonso de Albuquerque's pre-Portuguese 'Javanese' map, partially reconstructed from Francisco Rodrigues' Book. Bijdragen tot de Taal-Land-en Volkenkunde 151(1): 76-99.

Spriggs, M.

1990 Archaeological and ethnoarchaeological research in Maluku, 1975 and 1977: An unfinished story. Cakalele $1: 47-60$.

1998 Research questions in Maluku archaeology. Cakalele 9(2):49-62.

Spriggs, M., AND D. Miller

1979 Ambon-Lease: A study of contemporary pottery making and its archaeological significance, in Pottery and the Archaeologist: 25-34, ed. M. Millett. London: Institute of Archaeology.

1988 A previously unreported bronze kettledrum from the Kai Islands, eastern Indonesia. IndoPacific Prehistory Association Bulletin 8:79-88.

Spriggs, M., P. Veth, and S. O'Connor

1998 In the footsteps of Wallace: The first two seasons of archaeological research in the Aru Islands, Maluku. Cakalele 9(2):63-80.

STAHL, A. B.

2001 Making History in Banda: Anthropological Visions of Africa's Past. New studies in archaeology. New York: Cambridge University Press.

STARK, K., AND K. LATINIS

1992 The archaeology of sago economies in Central Maluku: An initial sketch. Cakalele 3:6986.

1996 The response of the early Ambonese foragers to the Maluku spice trade: The archaeological evidence. Cakalele 7:51-67.

Stoler, A. L.

1985 Capitalism and Confrontation in Sumatra's Plantation Belt, 1870-1979. New Haven: Yale University Press.

SuArez, T.

1999 Early Mapping of Southeast Asia. Hong Kong: Periplus Editions.

SWADLING, P.

1996 Plumes from Paradise: Trade Cycles in Outer Southeast Asia and Their Impact on New Guinea and Nearby Islands until 1920. Papua New Guinea National Museum. Papua New Guinea: Boroko.

TAYLOR, J. G.

1983 The Social World of Batavia: European and Eurasian in Dutch Asia. Madison: University of Wisconsin Press.

Tiвbetts, G. R.

1979 A Study of the Arabic Texts Containing Material on South-East Asia. Publications v. 44. Leiden: E. J. Brill for the Royal Asiatic Society. 
Trouillot, Michel-RolPh

1995 Silencing the Past: Power and the Production of History. Boston: Beacon Press.

"TWEEDE"

1601 Het Tvveede Boeck, journael oft dagh-register, inhoudende een warachtich verhael ende historische vertellinghe vande reyse, gedaen door de acht schepen van Amstelredamme, gheseylt inden maent martij 1598. onder 'tbeleydt vanden Admirael Iacob Cornelisz. Neck, ende Wybrant van VVarvvijck als vice-admirael. . . . Met . . . een vocabulaer van hare woorden. Middelburg: Barent Langhenes.

Ucko, P. J., AND R. LAyton, eds.

1999 The Archaeology and Anthropology of Landscape. London: Routledge.

Valentijn, F.

1724 Oud en Nieuw Oost-Indien, Vervattende een naaukeurige en uitvoerige verhandelinge van Nederlands mogentheyd in die gewestenk, benevens eene wydluftige beschryvinge der Moluccos. 5 vols. Dordrecht: J. van Braam.

1858 Oud en Nieuw Oost-Indien. Originally published 1724, vol. 3. Gravenhage: H. C. Susan.

VAN DER CHIJS, J. A.

1886 De Vestiging van het Nederlandische Gezag over de Banda-Eilanden (1599-1621). Batavia: Albrecht and Co.

Veth, P., S. O'Connor, And M. Spriggs

1996 After Wallace: Preliminary results of the first season's excavation of Liang Lemdubu, Aru Islands, Maluku. Paper presented at the Southeast Asian Archaeology 6th International Conference of the European Association of Southeast Asian Archaeologists, Leiden.

VILLIERS, J.

1981 Trade and society in the Banda islands in the sixteenth century. Modern Asian Studies 15(4) : 723-750.

1990 The cash crop economy and state formation in the Spice Islands in the fifteenth and sixteenth centuries, in The Southeast Asian Port and Polity: Rise and Demise, ed. J. Kathirithamby-Wells and J. Villiers. Singapore: Singapore University Press.

WALL, V. I. v. d.

1928 De Nederlandsche Oudheden in de Molukken. 's Gravenhage: Martinus Nijhoff.

WILSON, S. M.

1993 Structure and history: Combining archaeology and ethnohistory in the contact period Caribbean, in Ethnohistory and Archaeology: Approaches to Postcontact Change in the Americas: 19-30, ed. J. D. Rogers and S. M. Wilson. New York: Plenum Press.

WINER, $M$.

1995 The painted, poetic landscape: Reading power in nineteenth-century textual and visual representations of the Eastern Cape frontier. Kroeber Anthropological Society Papers 79:74109.

ZANDVLIET, K.

1998 Mapping for Money: Maps, Plans and Topographic Paintings and Their Role in the Dutch Overseas Expansion during the 16th and 17th Centuries. Amsterdam: Batavian Lion International.

\section{ABSTRACT}

Archaeological settlement data from the late precolonial Banda Islands of Indonesia is combined with information gathered from historic maps to investigate the process of cross-cultural interaction. In this case, the two data sets are biased and incomplete, but when combined can illuminate aspects of the late precolonial period in Banda that are otherwise hidden. The study uses European drawn maps dating from the late sixteenth to the early eighteenth centuries, and archaeological data from four sites on the islands of Banda Naira, Banda Besar, and Pulau Ay dating from A.D. 500-1700. Combined, the two sets of data suggest that European observers left certain settlements off of maps because of either lack of access or knowledge, or as deliberate means of deemphasizing Bandanese resistance to European colonial efforts. They also suggest that Europeans interacted primarily with Muslim-oriented settlements in Banda. Keywords: Banda Islands, Maluku, colonialism, historical archaeology, maps, settlement. 